\title{
CROSS-BORDER CO-OPERATION BETWEEN NORTHERN IRELAND AND \\ THE REPUBLIC OF IRELAND: NEO-FUNCTIONALISM REVISITED
}

\author{
Etain Tannam
}

IBIS working paper no. 40 


\title{
CROSS-BORDER CO-OPERATION BETWEEN NORTHERN IRELAND AND THE REPUBLIC OF IRELAND: NEO-FUNCTIONALISM REVISITED
}

\author{
Etain Tannam
}

Working Papers in British-Irish Studies

No. 40, 2004

(also printed as

MFPP ancillary paper no. 1)

Institute for British-Irish Studies

University College Dublin 
IBIS Working Papers

No. 40, 2004

(also printed as

MFPP ancillary paper no.1)

(C) the author, 2004

ISSN 1649-0304 


\section{CROSS-BORDER CO-OPERATION BETWEEN NORTHERN IRELAND AND THE REPUBLIC OF IRELAND: NEO-FUNCTIONALISM REVISITED}

This paper re-visits the theme of the reasons for economic co-operation between Northern Ireland and the Republic of Ireland and whether economic co-operation spills over to political co-operation. The article examines the impact of the Good Friday Agreement on cross-border administrative and economic co-operation and concludes that it has had a large impact on administrative co-operation, but that it has not provided large-scale incentives for business co-operation. Thus, different strategies for increasing co-operation are required for different sectors.

\section{Publication information}

Paper first presented to European Consortium for Political Research (ECPR) Joint Workshop, "The European Union and Conflict Resolution", Uppsala, 13-18 April 2004. 
Etain Tannam is Academic Fellow at the Dublin European Institute, UCD and is the author of Cross-Border Co-operation in the Republic of Ireland and Northern Ireland (Macmillan, 1999). She has written various articles on the cross-border relationship. 



\title{
CROSS-BORDER CO-OPERATION BETWEEN NORTHERN IRELAND AND THE REPUBLIC OF IRELAND: NEO-FUNCTIONALISM REVISITED
}

\author{
Etain Tannam
}

\section{INTRODUCTION}

This article re-visits the question of whether economic co-operation can spill over to political co-operation in a case of ethnic conflict-Northern Ireland. Previous research has examined the impact of the European Union (EU) on economic and political co-operation between Northern Ireland and the Republic of Ireland (Tannam, 1999). The theoretical framework used was neo-functionalism, where the hypothesis was that common economic interests would lead to economic cross-border cooperation. This economic co-operation would eventually spill over to political crossborder co-operation. The conclusion drawn ten years ago was that actors adopted a rationalistic economic cost-benefit analysis to apparent incentives for crossborder co-operation. However, in many areas, actors in Northern Ireland and the Republic of Ireland perceived each other as rivals for resources, rather than as cooperators. Political intervention by both Irish and British governments, rather than the existence of common economic interests, was found to be the most important explanation for cross-border economic co-operation. However, in certain sectors, perceptions of common economic interests had led to cross-border co-operative initiatives, particularly in aspects of business. The questions addressed in this paper are:

- Has the establishment of cross-border institutions under the Good Friday Agreement (1998) led to increased cross-border economic and political co-operation?

- Have economic cross-border initiatives in the early 1990s created a dynamism in Irish-Northern Irish relations, whereby numbers of cross-border initiatives and levels of cross-border trade have multiplied, even if the original incentives for such co-operation were political?

- What is the role of the European Union (EU) in advancing Irish-Northern Irish cooperation?

- What are the implications of the empirical findings for integration theory?

The methodology used is based on primary reports from key organisations involved in advancing cross-border co-operation or in administering EU money, on interviews with key actors involved in the administration of cross-border initiatives and on secondary research on the Good Friday Agreement (Good Friday Agreement) and the European Union (EU) dimension ${ }^{1}$

\footnotetext{
${ }^{1}$ Interviews were conducted with civil servants from the Irish Department of Foreign Affairs, Irish Department of Finance, the North/South Ministerial Council Secretariat and with representatives of Tourism Ireland and Co-operation Ireland.
} 
In the first section, an overview of neo-functionalism and the Irish-Northern Irish relationship until 1992 is provided. In section two, an overview of Strand Two of the Good Friday Agreement and of EU initiatives is provided, followed by an assessment of the Good Friday Agreement and the EU's impact on the cross-border relationship. In conclusion, an assessment of the relevance of neo-functionalism to the Irish-Northern Irish case is provided.

\section{NEO-FUNCTIONALISM AND THE CROSS-BORDER RELATIONSHIP, 1980-} 1996

Neo-functionalists emphasised the significance of political and economic élites in causing integration and the necessity for central political institutions to harness these elite activities and provide the dynamism to create a federal region.

The concept of spill over was central to the neo-functionalist argument. The distinction between high and low politics was taken as a starting point. High politics referred to questions of national defence and security (Hodges, 1972: 24). Low politics referred to the economic aspects of policy making. Economic co-operation was perceived to be politically neutral and less contentious. However, with the expansion of the welfare state, low politics had come to dominate state policy to an unprecedented degree by the late 1950s in industrialised West European states.

The expansion of low politics meant that, in fact, even economic policy necessitated political activity. Thus, neo-functionalists argued that functional economic cooperation in areas where little conflict existed would spill over to political cooperation. Economics would permeate political realms and the distinction between high and low politics would become blurred. Interest groups were assumed to be pivotal to the integration drive: "Integration proceeds most rapidly when it responds to socio-economic demands from the industrial urban environment, when it is an adaptation to cries for increasing welfare benefits born of a new type of society" (Haas, 1970: 102).

Indeed, according to one neo-functionalist interpretation, much pressure for the development of the European Community originated in the business communities of the founder states (Lindberg and Scheingold, 1972). These communities influenced their political leaders and an elite socialisation process in favour of deeper integration occurred. Through these interest groups, economic co-operation spilled over to political co-operation and, according to neo-functionalists, central political institutions became the driving force of Community formation (Harrison, 1978: 254). Once formed, the supranational institution was to provide an underlying dynamism for the integration process. Ernest Haas described the key purpose of the central institution as that of "upgrading common interests" (1970: 96). The existence of a central institution is vital, according to neo-functionalists, to mediate and upgrade common interests between interest groups and states. The central institution's interaction with national agents was also to be used as a measure of integration. Integration for neo-functionalists was less a condition and more a process. This process was to be measured by the degree to which national groupings transferred authority and legitimacy from the national state to the supranational central institution (Lindberg 
and Scheingold, 1972: 291). The goal of the integration process was the attainment of a federal union of states.

Neo-functionalism may be used to account for the effect of EU policy upon key domestic actors by explaining how the EU "upgrades common interests". The formulation of new EU policies, in particular the Single European Market (SEM) and the reform of EU regional policy, would increase the number of common economic interests shared by business groups in Northern Ireland and the Republic.

The SEM initiative aimed to achieve a single European market whereby all obstacles to trade would be abolished. Hence, theoretically, the initiative would increase Irish/Northern Irish trade. Moreover, incentives would be provided for cross-border lobbying and joint ventures to take advantage of a larger Irish/Northern Irish market. Moreover, regional policy reform to aid the then weaker economies provided incentives for local areas to co-operate across borders - receiving EU funding was made conditional on such cross-border co-operation.

For neo-functionalists, these new common interests would provide a basis for increased economic co-operation. However, as economic co-operation increased then so too would the demands of these élites for overarching co-ordinating political structures, that is for political co-operation. In the context of the conflict in Northern Ireland, the demands for overarching political structures would be preceded by communication and meetings between politicians from Northern Ireland and the Republic. This is also a form of political co-operation. For neo-functionalists, such political co-operation on the basis of economic co-operation is possible, but, unlike functionalism, the role of the Commission and the EU is vital in achieving such cooperation.

Thus, there were strong theoretical reasons why the EU might be expected to have an effect on the cross-border business relationship, as well as empirical reasons based on the effects of the Single European Market. However, in practice, the evidence of neo-functionalist logic in the Irish-Northern Irish case was less than overwhelming.

\section{IRISH-NORTHERN IRISH CROSS-BORDER RELATIONSHIP, 1988-1996}

In this section, an overview of business, bureaucratic and political cross-border cooperation is provided for the period 1988 to 1993. Co-operation is defined as existing where "actions of separate individuals or organisations-which are not in preexistent harmony-be brought into conformity with one another through a process of negotiations, which is often referred to as policy negotiation" (Keohane, 1984: 51). In the Irish-Northern Irish case, possible indicators of co-operation were identified along a continuum as indicated in table 1.

Table 1. Indicators of Cross-Border Co-operation

1. Informal contacts

2. Formal meetings

3. Joint Studies

4. Formulation and agreement of joint programme

5. Administration of joint programme

6. Development of further programmes

7. Establishment of cross-border institutions to administer current and future programmes Shared authority 


\section{Source: Tannam, 1999: 2}

The sensitivity of cross-border co-operation arose from the perception among unionists that such co-operation was one step on a slope towards a united Ireland. Indeed, for some nationalists, cross-border co-operation was embraced as tool to achieve a united Ireland. Thus, talks between Sean Lemass, then Irish prime minister and Terence O'Neill, then Northern Irish prime minister, foundered as the general political situation in Northern Ireland deteriorated in 1966-69 (Mansergh, 2001: 3 ). Similarly, the Sunningdale Agreement collapsed under the weight of unionist opposition to its cross-border executive council.

However, in the aftermath of the Single European Act (SEA), calls for increased economic co-operation to maximise Irish and Northern Irish markets increased, led particularly by members of both unionist and nationalist business communities, as well as business leaders in the Republic of Ireland. For the period 1988-94, cooperation was typified by the first three indicators of co-operation, with a few flagship joint projects or programmes), such as the opening of the BallinamoreBallyconnell canal which straddled the border (Tannam, 1999: 133). Cross-border business conferences spear-headed by the Irish Business Employers Confederation (IBEC)-Confederation of Business for Northern Ireland (CBI-NI) Joint Council and also by the Irish and Northern Irish Chambers of Commerce were oftmentioned examples of cross-border co-operation (Tannam, 1999: 142-3). ${ }^{2}$

Similarly, the creation of the SEM provided incentives for administrative crossborder co-operation. The administration of EU cross-border programmes financed by Interreg involved Irish and Northern Irish membership of monitoring committees to oversee the implementation of the programmes (Tannam, 1999: 157). Moreover, the EU's tourism, agriculture and transport programmes all had implications for administrative cross-border co-operation, emphasising the development of Northern Ireland and the Republic of Ireland as an island economy seeking to overcome its peripheral status.

EU programmes and the need to overcome peripherality in the SEM were also advocated to provide incentives for local councillors on both sides of the border to develop stronger links in planning development to cope with joint problems faced and in lobbying jointly for resources from Irish and British governments and from the EU. Thus, a Europe of the Regions and the concepts of subsidiarity and partnership appeared to provide incentives for increased local community cross-border cooperation (Tannam, 1999: 104-109). In practice, the role of the EU was most predominant in advancing localised cross-border co-operation (see below) and AngloIrish policy initiatives played the most important role overall in advancing crossborder co-operation. Table 2 provides an overview of cross-border co-operation, 1988-1996.

\footnotetext{
${ }^{2}$ The IBEC-CBI(NI) Joint Council comprised four members from each employer's union who worked intensively towards the aim of achieving closer cross-border economic co-operation to maximise the potential of Irish and Northern Irish markets.
} 
Table 2. Cross-Border Co-operation Between Northern Ireland and the Republic of Ireland, 1988-1996

\begin{tabular}{lccc}
\hline Actor & $\begin{array}{l}\text { Widespread economic } \\
\text { co-operation }\end{array}$ & $\begin{array}{l}\text { Limited economic } \\
\text { co-operation }\end{array}$ & $\begin{array}{l}\text { Political } \\
\text { co-operation }\end{array}$ \\
\hline Civil Service & No & Yes & No \\
MEPs & No & Yes & No \\
Local Government & No & Yes & No \\
Business & Yes & N/A & N/A \\
Agriculture & No & Yes & N/A \\
\hline
\end{tabular}

Source: Tannam, 1999: 201.

For the two civil services, in Northern Ireland and in the Republic of Ireland, there were perceptions of conflicts of interest and of compartmentalisation of interests. Therefore, the impact of EU cross-border programmes, or of other EU programmes with implications for cross-border co-operation, was limited to a handful of officials who were involved in a given scheme (Tannam, 1999: 160). Membership of monitoring committees administering EU programmes differed according to each policy area, but also each section of a policy area. Overall, there was very limited coordination between programmes. The breadth of cross-border administrative cooperation was thus impeded (Tannam, 1999: 161).

In addition, conflicts of economic and political interests impeded cross-border administrative co-operation. Tourism, inward investment and investment in Irish ports and in transport generally were two key areas of conflict-for example, investment in Dublin-Belfast road links at the expense of developing Dublin-Cork links. For Northern Irish civil servants, EU funding was not perceived to be as significant as British funding, and Northern Irish policy on the EU was governed by the then Conservative British administration, differing significantly from Irish policy on the EU (Tannam, 1999: 163). Thus, "for many civil service departments, there [were] no short-term benefits to be derived from cross-border co-operation" (Tannam, 1999: 162). The Anglo-Irish Division (AID) of the Irish Department of Foreign Affairs was the main civil service department seeking to advance to cross-border co-operation.

Politically, ideological divisions which governed political responses to cross-border co-operation (see above) implied that nationalist parties (the Social Democratic and Labour Party, SDLP, and Sinn Féin, SF) supported and welcomed cross-border cooperation, but unionist parties (the Ulster Unionist Party, UUP, and the Democratic Unionist Party, DUP) opposed it. The DUP particularly painted cross-border cooperation as "sinister" and an "evil genius" (Hainsworth, quoted in Tannam, 1999: 174) and opposed the EU-commissioned Haagerup Report. However, in practice Irish MEPs co-operated to receive EU funds and to lobby against CAP reform (Tannam, 1999: 179). The UUP adopted a more moderate response to the EU and to cross-border co-operation and heralded a weakening of partisan-linkage politics from 1994 (Tannam, 1999: 182). However, all unionist parties opposed institutionalised cross-border co-operation as envisaged by the Joint Framework Document in 1995. 
A noteworthy feature of cross-border political co-operation was evidence of increased local political co-operation between unionist and nationalist politicians along the border area. Special cross-border committees received fresh dynamism from EU regional policy to advance local economic development (Tannam, 1999: 187). These committees increasingly provided forums for meetings between unionist and nationalist councillors on both sides of the border. Cross-border conferences were well-attended by all parties, and preparation of joint studies and of project proposals became a large focus of cross-border activity. Local councillors observed a growing consensus among all councillors on cross-border economic issues, but again coordination problems and an absence of information weakened opportunities for such co-operation. Moreover, cross-border co-operation became linked to the aim of increasing local governmental autonomy in Northern Ireland and replacing the Anglo-Irish Agreement.

The business sector also provided evidence of increased cross-border cooperation, albeit limited. Cross-border business conferences and an atmosphere of change permeated accounts of the cross-border business relationship in early 1990s (Tannam, 1999: 141). The CBI-NI, IBEC and the Irish and Northern Irish Chambers of Commerce all lobbied for and organised cross-border initiatives, seeking to maximise the benefits of Irish and Northern Irish markets. For example, Chamberlink was established in 1994 to develop a joint economic strategy for the border area (Tannam, 1999: 144). Trade between Northern Ireland and the Republic of Ireland enjoyed a gradual increase, 1989-96. Mobility increased between Northern Ireland and the Republic of Ireland in terms of passengers crossing the border. Moreover the Irish and Northern Irish tourist boards began to co-operate closely to increase numbers visiting each jurisdiction (Tannam, 1999: 146-8).

However, there were obvious limitations to business cross-border co-operation. Trade still only constituted 5\% of total trade for both sides (Tannam, 1999: 149). Large firms were found to look to bigger markets, not to an "all-island" economy (Tannam, 1999: 150). Different exchange rates hindered trade (O'Dowd et al cited in Tannam, 1999: 150). Thus, economic obstacles to cross-border co-operation existed and government intervention was argued to be necessary if such co-operation was to increase (Bradley, 1996: 140).

Overall, continuity and some change characterised the cross-border relationship, but the most striking feature of the cross-border relationship was the impetus provided not by the EU, nor significantly by businesses, or civil servants in general, but by British and Irish governments. The European Commission itself followed the lead of British and Irish governments and was willing to provide financial support, but did not play a pro-active role in advancing reconciliation or political cooperation. There was no identifiable Commission policy to Northern Ireland and, indeed, many groups were entirely ignorant of the conflict. Moreover, some interviewees observed that in general the Commission was afraid of getting involved in the conflict.

However, in 1998, the political and economic landscape of cross-border cooperation altered dramatically with the inclusion of cross-border institutions in the Good Friday Agreement (Strand Two of the Good Friday Agreement). Simultane- 
ously, the EU's potential impact altered, because of Irish regionalisation in response to European Commission demands and because of EU-funding to underpin the peace process. In the remainder of this article the effect of the Good Friday Agreement and of the recent EU dimension is assessed. In the next section the new provisions for cross-border co-operation under the Good Friday Agreement and the EU's new provisions are examined before assessing their impact on the Irish-Northern Irish relationship.

\section{THE GOOD FRIDAY AGREEMENT, THE EU AND \\ CROSS-BORDER CO-OPERATION, 1998-2003}

\section{The Good Friday Agreement's implications for cross-border co-operation}

The Good Friday Agreement provided for a power-sharing executive within Northern Ireland, with devolved powers over specified areas and Assembly elections by PR-STV. Strand Two of the Good Friday Agreement was of key relevance to crossborder co-operation. The North/South Ministerial Council (NSMC) was established to develop "consultation, cooperation and action within the island of Ireland, including through implementation on an all-island and cross-border basis - on matters of mutual interest within the competence of Administrations, North and South". A British-Irish Council (BIC) was also established, comprising representatives of the British and Irish Governments and devolved institutions in Northern Ireland, Scotland and Wales and if appropriate, elsewhere in the United Kingdom, and of adjacent crown dependencies. There was a new British-Irish Intergovernmental Conference which would subsume both the Anglo-Irish Intergovernmental Council and the Intergovernmental Conference established under the Anglo-Irish Agreement of 1985.

The NSMC resembles the EU style of policy-making in some respects. The plenary meetings of the NSMC comprise the Irish Prime Minister (Taoiseach), the Northern Irish First Minister and Deputy First Minister. Like the EU, emphasis is on reaching decisions in designated areas by consensus (Coakley, 2002: 8). Sixty areas of cooperation were discussed in the negotiations which preceded the Good Friday Agreement, but only 12 areas were agreed upon. In six of these, implementation bodies were established. Table 3 provides a list of the key areas of co-operation and implementation bodies established under the Good Friday Agreement.

The areas of co-operation comprised areas where an economic need for crossborder co-operation was recognised (see table 3), but where various objections existed to establishing implementation bodies. Some objections were driven by unionist alarm at a perceived large Irish dimension (De Bréadúin, quoted in Coakley, 2002: 8): "The unionist concern has been to ensure that the North-South or Irish dimension does not acquire a momentum of its own that will undermine the union" (Mansergh, 2002: 4).

Table 3. Implementation bodies and areas of co-operation, Good Friday Agreement

\section{Implementation Bodies}

Inland waterways

Special EU Programmes

Food safety

Trade and Business Development

Language

\section{Areas of Co-operation}

Agriculture

Education

Environment

Health

Tourism 
Source: Coakley, 2002.

Thus, the negotiations which preceded the Good Friday Agreement highlighted accountability and legality issues in respect of the new institutions (Mansergh, 2001: 5). There was also bureaucratic resistance, highlighted above, in Irish and Northern Irish civil service departments (Coakley, 2002: 10). However, as the next section shows, civil service involvement in cross-border co-operation was generally more significant than in the period to 1998.

The NSMC is administered by a secretariat, originally comprising 24 civil servants drawn from the Irish civil service and the Northern Irish civil service (Coakley, 2002: 13). Two Joint Chairpersons head the Secretariat, one from Northern Ireland and one from the Republic of Ireland. The implementation bodies comprise members from the relevant sectors, from both Northern Ireland and the Republic of Ireland.

Membership of the implementation bodies comprises members of the business and civil service sectors. In addition, the Special EU Programmes Body (SEUPB) continues to be subject to monitoring committees, comprising Commission officials, as well as business and governmental representatives. The inclusion of the SEUPB implementation body implies that there are overlaps between the Anglo-Irish dimension of cross-border co-operation and the EU dimension.

\section{The EU's implications for cross-border co-operation}

Two main factors potentially altered the significance of the $\mathrm{EU}$ in the Irish-Northern Irish relationship. First, the amount of money provided by the EU to foster crossborder co-operation and to underpin the peace process generally increased. Second, in response to Commission criteria for regional funding, the six Irish border counties were designated as having "objective one" status. In order to receive maximum funding from the EU, administrative arrangements to ensure partnership and subsidiarity were demanded.

Irish objective one status. Before 1999, the Irish state constituted a single "objective one" region, under EU GDP criteria. However, the increased economic prosperity enjoyed in the 1990s led to the Commission altering this status. Thus in 1999 it was decided that only the Irish border regions met objective one criteria. The rest of the state and all of Northern Ireland were subject to transitional arrangements whereby they would have access to objective one funding, but on a gradually reducing basis until 2006 (SEUPB, 2003: 124). The identification of the Irish border region as objective one increased the incentives for Irish government to adhere to Commission requests for partnership and for evidence of subsidiarity. The identification of a separate region within the Republic of Ireland ended the congruence of central administration and regional status in the Irish case. Thus, changes in Irish objective one status had potential implications for the border regions and for crossborder co-operation. Moreover, under the EU's peace programmes, the financial incentives to increase cross-border co-operation multiplied.

EU funding: Peace 1 and Peace 2. In 1994, the EU established a task force to investigate assisting practically the Irish border counties and Northern Ireland (SEUPB, 2003: 98). The Peace 1 programme provided E300million under the 
Structural Funds umbrella, initially for a three year period. Nine per cent of the total allocation was allocated to cross-border development (SEUPB, 2003: 103). The new structures to deliver the funding were described as "a major development in terms of the level of devolved responsibility which it created" (SEUPB, 2003: 104).

Central government departments were involved in administering the money, but so too were district partnerships and Intermediary Funding Bodies (IFBs), comprising eleven voluntary organisations working to foster economic and social development. The district partnerships comprised one third elected members of the Northern Ireland local councils, one third of the community sector and one third of business representatives and trade union representatives (SEUPB, 2003: 106). Both the partnerships and the IFBs "were seen... as bringing an element of 'bottom-up development" (SEUPB, 2003: 105). Funding was allocated according to economic need and population size. The monitoring committee comprised Irish and Northern Irish department members and (22 civil servants) and nine Commission officials (SEUPB, 2003: 108).

The EU dimension was further strengthened financially when it was agreed that Peace 1 would be continued until 2004 (known as Peace 2), providing €500m to the border regions ( $€ 400 \mathrm{~m}$ to Northern Ireland and $€ 1 \mathrm{~m}$ to the six Irish border counties (SEUPB, 2003: 124). In addition, Interreg, Leader and other Community initiatives provided funding to Northern Ireland and the Republic of Ireland. Northern Ireland was allocated $€ 890 \mathrm{~m}$ and the Republic of Ireland was allocated $€ 3,200 \mathrm{~m}$ in total, under EU initiatives, some of which were specifically for cross-border cooperation (SEUPB, 2003: 125). A consultation process with local partnerships began about how EU money should be allocated (SEUPB, 2003: 126).

The main difference in the administration of Peace1 and Peace 2 was that under the new Good Friday Agreement arrangements a new implementation body, SEUPB, would be responsible for administering the programme (SEUPB, 2003: 132) and for liasing with the monitoring committee and the European Commission on managing Peace 2. The SEUPB chairs the monitoring committee, which comprises members of the Irish Department of Finance, Northern Irish department of Finance and Personnel, and business, voluntary sector, trade union and agricultural representatives (SEUPB, 2003: 134). Overall, as part of Strand Two of the Good Friday Agreement, the SEUPB is accountable to Northern Irish and Irish central authorities and represents a far more centralised form of managing EU money than the arrangements under Peace 1 (SEUPB, 2003: 132). It constitutes a forum for civil service cross-border co-operation and for increased co-ordination of Irish and Northern Irish policy (SEUPB, 2003: 134).

Moreover, local partnerships are still perceived to play an important role in economic development, but in Northern Ireland the role of local councils was enhanced at the behest of the new Assembly and of local councils in Northern Ireland (SEUPB, 2003: 136). The role of community or voluntary sector organisations was lessened. Thus the new partnerships comprised local government actors primarily, and secondly the social partners, including the voluntary sector (SEUPB, 2003: 137). In the Irish border region county council-led task forces exist, comprising state agencies, local development bodies, social partners and local government. 
Overall, changes in the Republic of Ireland's objective one status, increases in EU funding and the creation of new administrative structures to administer EU money potentially affected the cross-border relationship. The Good Friday Agreement both overlaps with this EU dimension (through the creation of the SEUPB) and also potentially provides an independent effect on cross-border co-operation. In the next section the impact of both the Good Friday Agreement and the EU on cross-border co-operation is assessed.

\section{THE EFFECT OF THE EU AND GOOD FRIDAY AGREEMENT ON CROSS-BORDER CO-OPERATION}

\section{The Effect of the Good Friday Agreement}

Civil service co-operation. The provisions for cross-border co-operation under the Good Friday Agreement had large potential implications for administrative, political and business behaviour. Administratively, the establishment of the NSMC and the Joint Secretariat in Armagh had obvious implications for cross-border civil service co-operation. The joint heads of the joint secretariat work closely together and are dedicated to co-ordinating and implementing cross-border initiatives in specified areas. Similarly, the staff based in Armagh are by definition involved in cross-border administrative co-operation.

The implementation bodies work closely with relevant civil service departments in Northern Ireland and the Republic of Ireland. For example, InterTrade Ireland "works in close collaboration with the Department of Trade and Investment, Belfast, the Department of Enterprise, Trade and Employment, Dublin and with the existing development agencies, North and South" (North/South Ministerial Council, 2002: 19). Similarly, the SEUPB comprises members of the Department of Finance and Personnel and the Irish Department of Finance. It works closely with a wide variety of civil departments, for example, agriculture, trade and enterprise and with local economic and political actors. The Community Initiatives Team "worked closely with the three Border Corridor Groups to set up the Interreg 111A Partnerships...(NSMC, 2002: 31). The SEUPB hosted a conference in 2002 involving local communities to discuss future areas of local cross-border co-operation. Overall, the SEUPB co-ordinates the activity of various actors involved in administering EU funds to Northern Ireland and the Republic of Ireland, providing greater coordination of the various monitoring committees involved in each EU programme.

The implementation bodies broaden levels of cross-border administrative cooperation by working with relevant civil service departments and divisions and other relevant actors. Such broad co-operation is central to their work (NSMC, 2002: 22). The areas of co-operation highlighted by the Good Friday Agreement (as opposed to the implementation bodies) provide a further basis for extended cross-border administrative co-operation. For example, Tourism Ireland's budget is subject to Department of Finance approval in Northern Ireland and in the Republic of Ireland (NSMC, 2002: 40). Its activities are closely engaged with Irish and Northern Irish departments of tourism. 
Areas of co-operation in the specified co-operation policy areas are agreed by the NSMC. Thus, Common Agricultural Policy (CAP) issues, animal and plant health policy and research and rural development were approved by the NSMC as areas of co-operation for initial consideration (NSMC, 2002: 45). Again, the agricultural departments from both jurisdictions are involved in developing this area. Overall, 65 NSMC meetings, including four plenary meetings occurred from 1998 to 2001, covering all areas of co-operation and the implementation bodies (AID, 2004: 1).

A key finding is that the administrative co-operation precipitated by the Good Friday Agreement is not restricted to a few civil servants involved in specific policy areas, as in the early 1990s (see above). Under the new administrative arrangements, each Dublin-based Irish civil service department of relevance to the NSMC's activities has a specific cross-border unit dedicated to liaising and co-ordinating activity with the NSMC and internally. ${ }^{3}$ This change was driven by the Good Friday Agreement requirement that Irish and Northern Irish ministers are responsible for designated areas of cross-border co-operation, thus wider civil service departmental involvement was deemed necessary. ${ }^{4}$ These units act as clearing houses for crossborder issues. ${ }^{5}$ They are chaired by senior civil servants and meet once a month to discuss cross-cutting issues with their Northern Irish counterparts. ${ }^{6}$

In addition, there is an overarching co-ordinating group in the Republic of Ireland, chaired by the Department of Foreign Affairs. ${ }^{7}$ Thus, knowledge of cross-border schemes and initiatives is not confined to those directly involved, but is a broader part of departmental activity. The two Departments of Finance play a key role in ensuring that the implementation bodies can operate effectively, by overseeing their operation. They are currently involved in setting out the accountability system underpinning the NSMC and its main bodies. ${ }^{8}$

The establishment of the North-South units and the emphasis on engaging with cross-border issues is driven politically "from the highest level". ${ }^{9}$ Both governments closely monitor cross-border co-operation in civil service departments to ensure such co-operation is prioritised. Thus, departmental perceptions of cross-border economic conflicts of interest, or reticence about developing cross-border cooperation, should not impede the aims of the Good Friday Agreement. ${ }^{10}$ Nor has the suspension of the Assembly reversed the co-operation already achieved. However, "in response to unionist concerns", it was agreed in 2002 that only policies and actions already mandated by the NMSC would be pursued, a policy of "care

\footnotetext{
${ }^{3}$ This section is based on interviews conducted with Irish civil servants from the Department of Foreign Affairs and Finance and the NSMC Secretariat during Spring 2004.

${ }^{4}$ interview, 06.04.04

${ }^{5}$ interview, 06.04.04

${ }^{6}$ interview, 06.04.04

${ }^{7}$ Interview, 06.02.04

${ }^{8}$ Interview, 06.02.04

${ }^{9}$ Interview, 06.02.04

${ }^{10}$ Interview, 06.02.04
} 
and maintenance" of cross-border co-operation (AID, 2004: 2). Since December 2002, "40 decisions have been taken to ensure that the North-South bodies and Tourism Ireland can continue to carry out their important work" (AID, 2004: 1). Despite the suspension of the Assembly, exploratory work continues to take place in Irish and Northern Irish departments on cross-border co-operation and on the EU dimension of co-operation.

Moreover, in 2003 a review of corporate governance of the North-South Bodies was initiated, to ensure that the new bodies "are fulfilling the highest levels of regulatory and financial compliance." It was also designed to fully address the unique all-island nature of the Bodies and the climate within which they operate" (AID, 2004: 3). Two cross-border civil service conferences have been held on the topic. A series of Corporate Governance Facilitation meetings was agreed upon, comprising the implementation bodies, their sponsor departments, each Finance department and the Joint Secretariat.

Thus, the Good Friday Agreement, despite the suspension of the Assembly has succeeded in achieving and maintaining co-ordination and co-operation between both civil services. Momentum has been provided at the highest level. For example, in early 2004, the Taoiseach and Irish Minister for Foreign Affairs "requested that Departments undertake an urgent review of the scope for co-operation in their Sectors..." (AID, 2004), despite the impossibility of initiating new cross-border proposals (ibid).

This high-level intervention and management as well as the establishment of the NSMC and secretariat have all diminished problems of information gaps and poor co-ordination among civil servants. Cross-border co-operation is part of the broader remit of civil service departments in the Republic of Ireland. Moreover, it has been observed that the NSMC Secretariat is perceived as the relevant institution in many of the Good Friday Agreement's policy areas, if an Irish or Northern Irish civil servant has a matter to raise or needs advice on a certain issue. ${ }^{11}$ Goodwill among civil servants on both sides of the border has been one of the major causes of optimism for those working in the NSMC Secretariat. However, despite this improvement in the administration of cross-border co-operation, there are still some problems in the administrative cross-border relationship.

\section{Obstacles to civil service co-operation ${ }^{12}$}

The existence of more extensive civil service co-operation and co-ordination procedures does not imply that there are no longer conflicts of interest between civil service departments. Thus, there is commonality, but also tension about certain issues, where economic priorities between Irish and Northern Irish civil service departments differ. ${ }^{13}$ The implementation bodies found themselves hamstrung at times because of their obligation to report back to their sponsor departments. It was observed that "coordination must not take place to the detriment of innovative

\footnotetext{
${ }^{11}$ Interview, 12.03 .04

12 This section is based on interviews with civil servants and representatives of Co-operation Ireland

13 Interview, 06.02.04
} 
cross-border work" (Co-operation Ireland, 2003: 3). While there is greater networking at high level to overcome conflicts of interest, cross-border sponsor department meetings occur only once a year approximately. ${ }^{14}$

Moreover, while Irish departments have established North-South units, Northern Irish departments have not done so. Thus, one interviewee found co-ordination and leadership problems existed in Northern Ireland, even if the situation had improved in the Republic of Ireland. ${ }^{15}$ While in the Republic of Ireland impetus was given by the Department of Foreign Affairs and the Taoiseach, in Northern Ireland, high-level governmental impetus was absent. ${ }^{16}$ This leadership problem extends also to management of the implementation bodies. Some bodies, for example, the SEUPB, do not have a Board and CEO, but merely a monitoring committee. Thus, strategic vision is limited: ${ }^{17}$

No actor plays a coordinating role to ensure that all departments (north and south), north-south implementation bodies and other partnerships at the statutory level are working towards a single over-arching objective and the impact of policies are compatible with this objective (Co-operation Ireland, 2003: 9).

While there are improvements in co-ordination arrangements governing crossborder administrative co-operation, "it is not clear that policies and programmes through which public funding for cross-border economic development are allocated are developed with reference to cross-border activities ongoing in other spheres such as service delivery, business to business co-operation and socio-economic development in the border region (Co-operation Ireland, 2003:10). There is still, according to this view, "a lack of sharing of information between policy-makers involved in promoting cross-border co-operation in different spheres... lack of coordination and joined-up policy-making" Co-operation Ireland, 2003: 14).

Thus "emphasis... on partnership, genuine contact and exchange between promoters and beneficiaries and between bodies, organisations and networks on both sides of the border" (Laffan and Payne, 2001: 139) is needed. As regards Interreg specifically, "projects tended to be appraised and agreed within the department working group and according to the policy priorities for that administration" (Laffan and Payne, 2001: 76-77). Therefore, joint cross-border management of Interreg was relatively weak.

Moreover, political obstacles to cross-border co-operation affect levels of bureaucratic co-operation. For example, it was particularly difficult to establish crossborder promoters and beneficiaries and between bodies, organisations and networks in transport co-operation, because the Northern Irish Minister for Transport was a member of the DUP and opposed cross-border co-operation on ideological grounds. His department was apparently not free to engage with the work of the NSMC. Similarly, the suspension of the Assembly and the new political landscape

\footnotetext{
14 Interview, 06.02.04

${ }^{15}$ Interview, 11..02.04

${ }^{16}$ Interview, 11..02.04

${ }^{17}$ Interview, 11..02.04
} 
in Northern Ireland, where the DUP has the largest proportion of political support have meant that the NSMC cannot play a pro-active role in developing co-operation for fear of causing a negative political response. ${ }^{18}$ The current difficulties have had a slight effect on levels of enthusiasm for cross-border co-operation. ${ }^{19}$

Overall, in administrative co-operation, there is evidence of improvements derived from the NSMC's establishment and from high-level governmental impetus, but there is still some criticism of strategic vision, of only moderate co-ordination and of ideological or political obstacles to developing cross-border co-operation. Neither the Good Friday Agreement's institutions nor the EU have overcome these obstacles. Indeed, the EU's role in civil service co-operation has been far less central than the Good Friday Agreement's impact. However, as the next section shows, the EU's impact on local border region co-operation has been greater. Moreover, there is a possible trade-off between co-ordination at central level and achieving local cross-border co-operation and partnership.

\section{Political cross-border co-operation}

While civil service behaviour is primarily governed by the impetus received from the Good Friday Agreement, local cross-border co-operation has been influenced by both the Good Friday Agreement's institutions and by the provision of EU-funding to underpin the peace process and to advance regional development. Thus, political cross-border co-operation is assessed in this section by examining local crossborder elations and also by examining the political parties' attitudes to cross-border co-operation as demonstrated in party manifestoes. Only DUP and Sinn Féin manifestoes are examined, because in the past, these parties most obviously linked cross-border co-operation to their political ideologies (see above).

Local Cross-Border Co-operation. The above EU initiatives as well as Strand 2 of the Good Friday Agreement have had implications for cross-border local cooperation. Three border groups, which were established before the Good Friday Agreement, ICBAN (Irish Central Border Area Network), NWBRG (North West Border Region Group) and EBRG (East Border Region Group) have all received impetus from the new administrative arrangements and increased funding. ${ }^{20}$ These groups are stronger because of their political dimension, whereby local councillors from all parties are actively involved and less likely to perceive local cross-border co-operation as step towards a united Ireland. ${ }^{21}$ ICBAN is a prototype for all the cross-border bodies' operation.

ICBAN comprises ten local authority representatives from all parties. Decisions reached by full consensus (ICBAN, 2002: 2). ICBAN has participated in transport projects, sales and marketing projects and information provision networking projects. These groups are actively engaged in lobbying the EU and national authorities. The border groups also meet as a partnership with social partners and county

\footnotetext{
${ }^{18}$ Interview, 6.03.04

${ }^{19}$ Interview 6.02.04

${ }^{20}$ Interview, 11.2.04

${ }^{21}$ Interview, 11.2.04 and interview, 06.02.04
} 
development board representatives. The partnership has 3 sub-committees, dealing with business and economic development, knowledge economy and human resources.

Thus, in the submission of programmes or projects to be funded and in the allocation of funding, NGOs, local authorities, local businesses are all involved. The Border Midland and Western regional assembly, set up after the establishment of the Committee of the Regions, also has implications for cross-border political cooperation. It comprises local councillors and is represented on the monitoring committees of Peace 11 and for Interreg $111 \mathrm{~A}$ and hence provides another forum for local political co-operation.

Similarly, for Peace 1, a Joint Management Committee (JMC) was established to oversee the programme's implementation. The JMC comprised five members from the border counties and five members from Northern Ireland as well as NGO representatives (SEUPB, 2003: 119). In addition, seminars and conferences were held with wide participation marking "the development of strong working relationships with a wide variety of stakeholders. Local advisory committees were established to identify gaps in practical administration of cross-border programmes and to identify 'best practice' in the area (SEUPB, 2003: 121). Under Peace 2, local council involvement was even greater as a consequence of the Good Friday Agreement and political parties' desire to increase local power. Thus, practitioners have observed that through ICBAN, NWBRG and Eastern Border Region Group, local crossborder political co-operation has increased..$^{22}$ Moreover, the activities of these local cross-border groupings and networks are not hindered by Northern Irish party leaders, as an examination of election manifestoes shows.

DUP and Sinn Féin Manifestoes. Practitioners have observed that the DUP does not express opposition to Strand 2, unless efforts are made to link economic cooperation to unification. ${ }^{23}$ In its recent manifestoes, it does criticise the NSMC and implementation bodies, but in a relatively measured manner. Thus, the DUP states it:

Will oppose any attempts to integrate the Northern Ireland economy with that of the Irish Republic whilst encouraging companies to export goods and services south of the border

The 2003 manifesto focussed more strongly on the NSMC. The manifesto accused the UUP of giving "Dublin unaccountable powers over affairs in Northern Ireland", a point reiterated in its review of the Good Friday Agreement (DUP, 2003b: 16). It accused the UUP of allowing the NSMC to operate despite the suspension of the Good Friday Agreement (DUP, 2003a: 8). Moreover, the DUP states that "uncontrollable all-Ireland bodies are the starting point for a united Ireland (DUP, 2003a: 12). However, among the DUP's recommendations is not that the NSMC be abolished, but that "any relationship with the Republic of Ireland must be fully accountable to the Assembly" (DUP, 2003a: 13).

\footnotetext{
22 Interview, 06.02.04

${ }^{23}$ Interview, 06.02.04
} 
Moreover, civil servants interviewed observed that in DUP-Irish government negotiations, no insurmountable opposition to the NSMC has emerged to date. ${ }^{24}$ Overall, while the DUP clearly exhibits its opposition to the implementation bodies, its opposition to cross-border co-operation in general has weakened. Moreover, since its success in the 2003 elections, it has a rationale to negotiate a successful settlement, in return for taking its seats in a new Assembly (Co-operation Ireland, 2003).

In Sinn Féin's manifestoes emphasis on cross-border co-operation as a means to achieving a unified Ireland has lessened. Thus, in 1997, its section on cross-border economic development focuses on the economic merits of cross-border cooperation (Sinn Féin, 1997: 5). In its 2001 manifesto it stresses its status as an "allIreland party" (Sinn Féin, 2001: 2), but again its emphasis on the NSMC is on its economic benefits and it refers frequently to the "island economy" and the economic distortions of partition (Sinn Féin, 2001, passim). Similarly in its 2003 manifesto, it asserts the aim of developing "all-Ireland structures to foster an Ireland of equals" (Sinn Féin, 2003: 20). It aims to use the NSMC "to effect (sic) co-ordination and integration of policy-making and programmes of work across the border and throughout Ireland" (Sinn Féin, 2003: 21). In discussing local cross-border cooperation, again, it emphasises the economic need for such co-operation. While clearly Irish unity is the aim of Sinn Féin, in recent manifestos it never explicitly links unity to the NSMC or to cross-border co-operation, but instead emphasises the economic rationale for co-operation.

Thus, the issue of cross-border co-operation per se has become less politicised for both the DUP and for Sinn Féin, a trend which emerged in the early 1990s. The DUP exhibits more evidence of explicit issue-linkage of the NSMC to Irish unity than does Sinn Féin. However, its language is more measured than in previous documents. The NSMC's accountability is emphasised by the DUP, but not its status per se. For Sinn Féin, an expansion of the NSMC's policy areas is favoured, but not linked to unity explicitly. This economic emphasis contrasts with its earlier statements, but again continues a trend which became evident in the early 1990s (Tannam, 1995).

Overall, political cross-border co-operation has increased at the local level and party attitudes to co-operation are less subject to "partisan-issue linkage" (see above). This trend is not caused by the Good Friday Agreement or by Peace 1 and 2 per se, because it began to emerge after the 1988 reform of the structural funds (Tannam, 1999). However, the Good Friday Agreement, and the EU's initiatives since 1999, have provided a further stimulus for attitudinal change. In the next subsection, the response of business to the Good Friday Agreement and the EU is assessed before examining the applicability of neo-functionalism to the Irish-Northern Irish case.

\section{Business cross-border co-operation}

There are two main areas of potential business co-operation: tourism and market promotion or networking to increase cross-border trade. As the next section shows,

\footnotetext{
${ }^{24}$ interview, 06.02.04
} 
tourism co-operation has proved relatively successful since the Good Friday Agreement, but trade promotion has been more problematic.

Tourism: The establishment of Tourism Ireland under the Good Friday Agreement is the cornerstone of tourism cross-border co-operation. The aim is to increase numbers visiting Northern Ireland and the Republic of Ireland and to allow Northern Ireland to increase its overall number of tourists. ${ }^{25}$ The overall goal is to double overseas spending by 2012 (Tourism Ireland, 2004a: 9). The main means of achieving these aims is through provision of information, hosting of cross-border seminars and conferences and facilitation of marketing endeavours (Tourism Ireland, 2004: 5). ${ }^{26}$

Table 4. Numbers of overseas visitors to Northern Ireland and the Republic of Ireland (000s), 1998-2003

\begin{tabular}{lrrrrrr}
\hline Year: & 1998 & 1999 & 2000 & 2001 & 2002 & 2003 \\
Visitors: & 6,316 & 6,852 & 7,154 & 6,899 & 7,061 & 7,300 \\
\hline
\end{tabular}

Source: Tourism Ireland, 2002: 1, Irish Times, "Business This Week", 12.03.04: 28.

The creation of Tourism Ireland coincided with a particularly turbulent international environment (September 11, the Iraq war, Foot and Mouth disease in the UK). Therefore, it is difficult to measure its success in terms of statistical outcomes. Indeed, table 4 demonstrates only marginal change in the overseas visitors. However, 2003 figures were greeted favourably by tourism leaders. Of the total number of visitors to the "island economy" approximately 80 per cent visited the Republic of Ireland only, $16 \%$ visited Northern Ireland only and $4 \%$ visited both areas (Tourism Ireland, 2002: 2). Thus, given the difficult international climate, tourism figures fared relatively well, albeit they had not dramatically increased.

Moreover, neither bureaucratic, business nor political conflicts of interest have proved an obstacle to tourism co-operation. Indeed, levels of agreement have been described as "excellent". ${ }^{27}$ However, as the system of policy formulation is relatively new, the decision-making process is under constant review. For example, Tourism Ireland is subject to controls from its two sponsoring departments, the two Finance departments and the NSMC, which in turn includes a broader set of departments. The bureaucratic process of finding approval for a given project is thus complicated. However, the NSMC's Corporate Governance project (see above) is perceived as providing an effective means of overcoming these practical problems. ${ }^{28}$

As regards conflicts of economic interest, Tourism Ireland, by increasing overall figures to both areas, avoids perceptions that one jurisdiction is gaining at the expense of the other-the total size of the pie is bigger. Nor has the DUP opposed tourism cross-border co-operation; thus political obstacles have been minimised. ${ }^{29}$

\footnotetext{
${ }^{25}$ Chairman Tourism Ireland interview with author, 06.4.04

26 Ibid

27 Ibid

${ }^{28}$ Interview, 06.04.04

${ }^{29}$ Interview, 06.04.04
} 
Overall, tourism co-operation has succeeded relatively well, given the international obstacles it faced, in increasing numbers of visitors to Northern Ireland and the Republic of Ireland, but particularly in increasing communication channels and in facilitating harmonious agreement. In contrast, efforts to increase trade promotion have been less successful to date.

Trade and business development. InterTradelreland has aimed to develop trade and business development by providing information to businesses on both sides of the border about business opportunities, a strategy adopted by IBEC/CBI-NI in the early 1990s (see above). Approximately 30 initiatives have been launched by InterTradelreland, most of which seek to establish new networks in various areas, for example, equity, science and technology, marketing, business information and digital technology (NSMC, 2002: 20). Business interest in many of the ventures is argued to be high. ${ }^{30}$ Thus, the FUSION programme bringing businesses, research centres and graduates together on a cross-border basis initially financed 40 projects and currently finances 140 . The key difference between InterTrade Ireland and the IBEC-CBI-NI Joint Council is that the former organisation is far larger and has a budget of $€ 40 \mathrm{~m}$. Moreover, there is much larger public sector involvement in InterTrade Ireland. Thus, its scale and potential are far greater. For practitioners, the key importance of these initiatives is their ability to bring business people from Northern Ireland and the Republic of Ireland together to discuss practical problems and exchange expertise. For members of the NSMC secretariat, InterTrade Ireland is succeeding in opening communication channels to an ever-increasing number of business people. ${ }^{31}$ Moreover, the administration of PEACE 1 and 2 involves local business actors from both sides of the border who meet regularly to devise and monitor development plans.

Thus, co-operation is fostered through information provision at seminars and conferences. As in the early 1990s, these seminars, conferences and joint promotion venture constitute the main examples of cross-border co-operation (see above), but activity has increased in scale: Joint promotions of Irish products overseas have been organised and strategic alliances are being encouraged between Northern and Southern firms (Bradley and Birnie, 2001: 33). However, in terms of tangible results, levels of cross-border trade have not increased, as table 5 shows:

Table 5. Cross-border trade of Republic of Ireland, 1998-2002

\begin{tabular}{lcc}
\hline Year & Imports from NI (\%) & Exports to NI (\%) \\
\hline 1998 & 2.7 & 2.6 \\
1999 & 2.6 & 2.3 \\
2000 & 2.2 & 2.1 \\
2001 & 2.1 & 2.0 \\
2002 & 1.9 & 1.7 \\
\hline
\end{tabular}

Source: Central Statistics Office, 2004: 22-23

\footnotetext{
${ }^{30}$ Interview, Chairman NSMC Secretariat,12.03.04

${ }^{31}$ Ibid
} 
Thus, not only have imports as a percentage of the total not increased, they have fallen marginally, indicating that the logic of cross-border trade does not compel businesses on both sides of the border, particularly large businesses. There is a number of possible reasons for the low level of cross-border trade. Physical peripherality and transport problems provide obstacles to cross-border business development. The problems in achieving closer transport co-operation spill over to the business cross-border relationship (Bradley and Birnie, 2001: 25). Moreover, differences in industrial structure between Northern Ireland and the Republic of Ireland impede cross-border trade. The Republic of Ireland has a more modern industrial base specialising in high-technology areas. In contrast, Northern Ireland has a greater concentration of industry in traditional manufacturing. The most important factor explaining EU trade patterns is the existence "of inter-firm trade in similar product areas, rather than trade in finished consumer goods" (Bradley and Birnie, 2001: 32). Thus, it is argued that "trade simply cannot easily take place between North and South, given the contrasting production structures". Another reason for low levels of trade is that small firms tend to have closer cross-border links, but constitute a smaller share of total trade. Moreover, British self-exclusion from EMU hinders the gains from trade for these small firms (Bradley and Birnie, 2001: 370).

Hence, there are market driven factors that help to explain why cross-border trade is low. However a key debate is whether governmental intervention can overcome these obstacles or not. Thus, it is argued that "semi-political interventions do not necessarily follow market signals...The intervention which has occurred has been directed almost exclusively towards North-South trading links as opposed to those between Northern Ireland and Great Britain", implying a political, rather than economic motivation (Bradley and Birnie, 2001: 74).

Indeed, the relationship between business cross-border co-operation and centralised institutional change is at the centre of the neo-functionalist argument. This paper has demonstrated significant administrative and institutional changes since 1998 in administering cross-border co-operation and has also highlighted the role of the EU in increasing local and regional administrative change and local crossborder political co-operation. However, the case of business highlights the existence of economic and infrastructural obstacles to cross-border co-operation. The question of whether institutional change can foster bottom-up co-operation "on the ground" in a situation of historical conflict, or whether bottom-up initiatives must precede or coincide with institutional change is at the centre of assessing the applicability of neo-functionalism to the Irish and Northern Irish relationship. In the remainder of this article the neo-functionalist approach is applied to this case in the light of the Good Friday Agreement and the EU's potential impact.

\section{CONCLUSION: NEO-FUNCTIONALISM AND THE CROSS-BORDER RELATIONSHIP, 1998-2003}

The neo-functionalists emphasised the role of economic elites demanding increased co-operation, led by political elites in a supranational institution which would upgrade common interests. Thus, both institutional change and economic activity is central to the neo-functionalist argument. In the Irish-Northern Irish case, 
calls for overarching institutions to foster cross-border co-operation were dominant in the years preceding the Good Friday Agreement. The economic argument was that market imperfections which hindered cross-border co-operation could be overcome by the creation of cross-border institutions, such as the NSMC (Bradley, 1996). The theoretical implication of this argument was that "bottom-up" cooperation would not occur in the absence of political institutional change.

In contrast, the period 1998-2003 was characterised by dramatic and innovative institutional change and by significant financial aid from the EU. These changes have had various effects. The most dramatic has been the response of civil services on both sides of the border. The highest degree of cross-border co-operation occurs at the administrative level. Thus, an important indicator of cross-border co-operation (over-arching institutions to administer co-operation) has occurred. However, this co-operation was politically driven by British and Irish governments. It was not a response to "economic cries" (Haas, 1970) and it was not a response to an upgrading of interests originating in the European Commission. Moreover, even if the institutional framework established under the Good Friday Agreement resembles the EU model (for example consensual politics and negotiation), spill over from this administrative co-operation has not occurred in many aspects of business cooperation. Tourism cross-border co-operation has proved successful, but in general levels of cross-border business co-operation have not altered significantly. Thus, neo-functionalism does not appear to explain administrative co-operation.

However, political cross-border co-operation has improved, both in terms of political parties' attitudes to cross-border co-operation and in terms of localised crossborder co-operation. This local cross-border co-operation is predominantly a result of EU-funding and monitoring mechanisms. Thus, the significance of the EU role in local co-operation does provide some evidence of neo-functionalist logic: the Commission provides economic incentives for economic co-operation which in turn facilitates political co-operation between local councillors.

Moreover, both the EU's role and the NSMC provide evidence that legitimacy and allegiance can be transferred to new institutions, to a degree. Thus, the monitoring and partnership systems with Commission involvement are viewed as the legitimate locus of authority for designated policy issues. Similarly, civil service departments on both sides of the border look to the NSMC and its secretariat in agreed areas to be responsible for specific policy issues. One of the most surprising results according to participants has been the degree of civil service goodwill and support to the NSMC since its creation. The operation of the NSMC secretariat has been compared to the EU model of political behaviour, whereby members behave consensually and seek to resolve conflicts of interest through communication. Moreover, like the EU example, the communication process itself has improved bureaucratic relations since 1999 and lessened information gaps and mistrust. ${ }^{32}$

However, overall, while participants in the cross-border process have been impressed by the NSMC and EU's achievements, concern has been expressed that linking the activities of the NSMC to "people on the street" has been more problem-

\footnotetext{
${ }^{32}$ Interview, 12.03.04
} 
atic. $^{33}$ Thus, spill over has not occurred. Apart from local council cross-border cooperation involving local business communities, bottom-up co-operation has not occurred in general, as indicated by business behaviour in Northern Ireland and the Republic of Ireland. There are two possible interpretations of this finding. Either spill over is so gradual that grassroot change will occur later on in the process., or, alternatively, a multi-pronged strategy is needed to advance widespread cross-border co-operation. The first argument about the gradual nature of spill over has been a constant feature of neo-functionalists' defence. In many ways, it seems plausible that an examination of 1988-2003, in the context of an historic conflict is only partially illuminating. However, for critics of neo-functionalism's applicability, there is little evidence of even gradual grass-root change in areas of urban deprivation where sectarianism is strongest.

Thus, it is argued that specific strategies are needed for different levels of society and for different sectors. This multi-pronged strategy will ensure widespread cooperation so that "The involvement of numerous actors ensures synergies between the different levels of integration and positive pullovers from one domain to another (Teague, quoted in Co-operation Ireland, 2003b: 6)

This type of approach implies that neo-functionalism's grand theoretical underpinning is misplaced in the Irish-Northern Irish context. By definition high-level intergovernmental institutional change will lead to increased administrative or bureaucratic co-operation. Engrenage caused by the creation of North-South institutions is far greater than any EU determinant of change. Thus, civil service co-operation has been governed by intergovernmental Anglo-Irish policy, not by supranational influences.

Similarly, different groups of actors respond to different incentives for change, some local, some centralised, some supranational. A mixture of incentives is required to increase cross-border co-operation, combining local, centralised and supranational factors. The linear causal progression of neo-functionalism, whereby economic demands lead to supranational institutional change which leads to economic and political co-operation does not fit this multi-levelled approach. However, the theoretical problem with this multi-pronged strategy is that while it may appear to be empirically desirable, it raises methodological problems. In particular the multi-level approach may be more a policy prescription than a theoretical model of change.

Overall, the above case study shows that the relationship between Northern Ireland and the Republic of Ireland has changed and has been influenced significantly by the Good Friday Agreement and the EU. However, re-visiting neo-functionalism in the light of these changes has not provided any evidence that neo-functionalism is a better fit in explaining the cross-border relationship. The logic of co-operation has remained similar to the logic evident in the period 1988-1995. Neo-functionalism fits some aspects of the relationship, but different groups of actors have distinctive responses to different sets of incentives for co-operation. Incentives specific to each group and sector, tailored to their own logic of co-operation, are needed to improve

\footnotetext{
${ }^{33}$ Interview, 6.02.04
} 
the overall cross-border relationship. The Good Friday Agreement has facilitated increased co-operation and coordination. The EU has also played a key role at the local level. However, neither the Good Friday Agreement nor the EU has provided sufficient conditions for generalised and significant cross-border co-operation to date. Thus, the answer to this paper's core question of assessing neofunctionalism's validity is a negative one. In contrast, the merits of a more holistic theoretical approach are defended by the case of the Irish-Northern Irish relationship.

\section{REFERENCES}

AID (Department of Foreign Affairs, Anglo-Irish Division) (2004) North/South co-operation: overview. Dublin: Department of Foreign Affairs

Bradley, J (1996) An island economy: exploring the long-term economic and social consequences of peace in Ireland. Dublin: Forum for Peace and Reconciliation

Bradley, J, and E Birnie (2001) Can the Celtic Tiger cross the Irish border? Cork: Cork University Press.

Central Statistics Office (2004) Statistics for North-South trade. Cork: Central Statistics Office

Coakley, J (2002) The North-South institutions: from blueprint to reality [IBIS Working Paper, no. 22]. Dublin: Institute for British-Irish Studies, University College Dublin

Co-operation Ireland (2003) The current need for North-South co-operation. Belfast: Cooperation Ireland

Democratic Unionist Party (2001) Leadership to put things right. Belfast: DUP

Democratic Unionist Party (2003) Towards a new agreement. Belfast: DUP

Haas, E (1970) "The study of regional integration", International organisation 24 (4): 91108

Harrison, R (1978) "Neo-functionalism", in P Taylor and A Groom, eds. International organisation: a conceptual approach. London: Pinter

Hodges, M (1972) European integration. Harmondswoth: Penguin

Keohane, R (1984) After hegemony: co-operation and discord in the world political economy. Princeton: Princeton University Press

Laffan, B and D Payne (2001) Creating living institutions: EU cross-border co-operation after the Good Friday Agreement. Armagh: Centre for Cross-Border Studies

Lindberg, S and L Scheingold (1972) Europe's would-be polity. New Jersey: Prentice-Hall

Mansergh, M (2001) Cross-border bodies and the North-South relationship: laying the groundwork [IBIS Working Paper, no. 12]. Dublin: Institute for British-Irish Studies, University College Dublin

North/South Ministerial Council (2002) Annual Report. Armagh: NSMC

SEUPB (2003) Building on peace: supporting peace and reconciliation after 2006. Monaghan: ADM/CPA

Sinn Féin (2003) Agenda for government. Dublin: Sinn Féin 
Tannam, E (1999) Cross-border co-operation in the Republic of Ireland and Northern Ireland. London: Macmillan

Tourism Ireland (2002) Facts and figures. Dublin: Tourism Ireland 